\title{
ANALISIS STRATEGI PENGEMBANGAN USAHA PENGOLAHAN IKAN PADA KAMPUNG PATIN, KAMPAR, RIAU
}

\author{
Sri Zuliarni ${ }^{1)}$ \\ Program Studi Ilmu Administrasi Bisnis, Universitas Riau, email: srizuliarni.ur@gmail.com
}

\begin{abstract}
Abstrak
Penelitian ini bertujuan untuk menganalisis strategi pengembangan usaha pengolahan ikan Kampung Patin., Kabupaten Kampar, Riau. Analisis data menggunakan metode deskriptif dan kualitatif dengan pendekatan SWOT. Berdasarkan sejumlah faktor lingkungan internal dan eksternal, maka terdapat delapan strategi pengembangan usaha pengolahan ikan Kampung Patin yang penting untuk diimplementasikan, diantaranya pemberdayaan sumber daya manusia, semakin meningkatkan kualitas produk olahan ikan, perluasan jangkauan pemasaran, peningkatan keterkaitan produksi antara Usaha Mikro Kecil dan Menengah (UMKM) dan Usaha Besar (UB), meningkatkan kompetensi sumber daya manusia, semakin meningkatkan kreatifitas dan keinovatifan pengusaha, mengupayakan pengemasan yang baik, menarik dan inovatif serta meningkatkan jalinan kerjasama antara Kampung Patin dengan Triple Helix sehingga terjadi modernisasi sarana dan teknologi pendukung untuk meningkatkan efisiensi dan daya saing usaha
\end{abstract}

Kata kunci: analisis SWOT, strategi pengembangan usaha, usaha pengolahan ikan 


\section{PENDAHULUAN}

UMKM memiliki peran vital dalam perkembangan ekonomi suatu negara. Demikianlah perspektif yang telah mendunia dan valid baik bagi negara berkembang maupun negara maju. Di Indonesia sebagai negara berkembang, diakui bahwa karakteristik-karakteristik UMKM yang membedakannya dengan Usaha Besar (UB), seperti UMKM adalah usaha padat karya, produksinya yang bergantung pada bahan lokal, tersebar di pedesaan dan perkotaan juga UMKM umumnya adalah usaha dalam rangka pemenuhan kebutuhan masyarakat, menjadikan Pemerintah Indonesia berupaya agar UMKM terus tumbuh, berkembang dan maju ditengah-tengah isu perdagangan bebas Masyarakat Ekonomi ASEAN (MEA 2015) yang pada intinya adalah tidak ada lagi hambatan terhadap arus barang dan jasa, manusia dan modal antara negara-negara anggota ASEAN.

Di Propinsi Riau telah tampak adanya perkembangan nyata UMKM yang merupakan hasil dari usaha keras triple helix (di Indonesia dikenal dengan ABG), yaitu sinergi dari Academician, Businesses and Government. Sebut saja, usaha pengolahan ikan di Desa Koto Mesjid, Kecamatan XIII Koto Kampar, Kabupaten Kampar yang telah mendapat julukan sebagai Kampung Patin. Desa Koto Mesjid juga didaulat oleh Direktorat Jenderal Pengolahan dan Pemasaran Hasil Perikanan (P2HP) - Departemen Kelautan dan Perikanan sebagai sentra pengolahan produk perikanan air tawar di Riau. Tidak hanya itu, Melalui Keputusan Menteri Kelautan dan Perikanan RI No. Kep.32/Men/2010 tentang Penetapan Kawasan Minapolitan, ditetapkan bahwa kawasan Minapolitan di Provinsi Riau berada di Kab. Kampar, yang dipusatkan pada wilayah Kecamatan XIII Koto Kampar dengan minapolis berada di Desa Koto Mesjid.

Berikut beberapa fenomena terkait pengembangan usaha sentra pengolahan ikan Kampung Patin, Kampar, Riau:

a. Berawal dari sebuah desa miskin yang merupakan tempat bagi transmigran lokal akibat pembangunan Pembangkit Listrik Tenaga Air (PLTA), desa Koto Mesjid kini telah berubah menjadi sebuah desa sejahtera melalui pengembangan industri ikan, khususnya ikan patin. Dengan motto "Tiada Rumah Tanpa Kolam Ikan", desa Koto Mesjid kini dikenal sebagai "Desa
Kampung Patin" dan berhasil meraih penghargaan Adibakti Mina Bahari Pembudidaya Teladan, juara satu Pengolahan Patin Tingkat Provinsi dan ditetapkan sebagai Desa Pengembangan Terpadu. Dengan prestasi ini, desa Koto Mesjid dijadikan sebagai percontohan bagi desa-desa lain di Riau, dan bahkan layak dijadikan percontohan bagi desa lain di seluruh nusantara dalam rangka meningkatkan taraf ekonomi masyarakat (djpen.kemendag.go.id, 2013).

b. Pada 2002 PT. Telkom melalui Program Kemitraan Bina Lingkungan (PKBL) yaitu kerjasama mitra binaan dalam pemberian bantuan modal usaha. Selanjutnya pada 2009, Kampung Patin ditetetapkan sebagai lokasi minapolitan berdasarkan Keputusan Bupati Kampar Nomor: 050/Bappeda/174/2009 dan tentang Pembentukan Kelompok Kerja (Pokja) berdasarkan Keputusan Bupati Kampar Nomor 138 Tahun 2009dengan komoditas unggulan ikan mas, patin, dan nila. Untuk usaha di bidang perikanan, sebenarnya sudah dimulai sejak tahun 1998 pada Desa Koto Mesjid. Pada tahun 2008, usaha sektor perikanan mengalami kemajuan dan memberikan "warna" tersendiri bagi desa Koto Mesjid. (Telkom, 2013).

c. Dalam pegembangannya mulai tahun 20032012 desa Koto Mesjid mendapat bantuan dari Pemerintah Kabupaten Kampar dan Pemerintah Propinsi Riau berupa bangunan tempat penyalaian dan perlengkapan lainnya senilai 9,2 M kepada 185 UKM di desa Koto Mesjid dan Pulau Gadang. Bahkan desa ini sudah meraih penghargaan Adi Bakti Mina Bahari pembudidaya teladan dan juara 1 pengolahan patin tingkat provinsi Riau. dan ditetapkan sebagai desa pengembangan terpadu. (Siagian, Ramli dan Nugroho, 2014).

d. Pada tahun 2003 pertama kali mendapat bantuan PKBL, , rata-rata penghasilan masyarakat kota ikan, Koto Masjid, hanya Rp2 juta hingga Rp3 juta per bulan, dengan jumlah tenaga kerja yang bergabung di bisnis ini hanya 87 orang serta hanya memiliki 132 kolam, 39 rumah permanen dan 13 mobil. Dan pada tahun 2011, ratarata penghasilan masyarakatnya menjadi Rp.5.000.000,- hingga Rp.6.000.000,- per bulan. serta menampung 216 tenaga kerja di 369 kolam ikan dan juga telah memiliki 
89 rumah permanen plus 44 mobil Artinya saat ini masyarakat Koto Masjid ekonominya semakin sejahtera. Berdasarkan data yang diperoleh telah berkurangnya ang a kemiskinan, yang sebelumnya 30\% menjadi 3\% yang masih miskin.

e. Sejak tahun 2010 hingga 2012, diperkirakan ekspor salai ikan patin sentra pengolahan ikan, Kampung Patin, Kampar, Riau ke negara Malaysia dan Singapur mencapai tiga ton (djpen.kemendag.go.id, 2013).

f. Desa Koto Mesjid (Kampung Patin) memiliki kolam seluas $\pm 230 \mathrm{Ha}$ dari luas wilayah keseluruhan desa tersebut seluas 425,5 Ha. Ikan patin merupakan salah satu ikan yang utama dibudidayakan di Desa Koto Mesjid dengan jumlah produksi ikan patin mencapai \pm 6 ton per hari atau sekitar 2.190 ton per tahun dengan jumlah kolam sekitar 776 kolam dengan total luas sebesar $52 \mathrm{Ha}$ (Dinas Perikanan Kabupaten Kampar, 2013 dalam Hasnibar, Hamid dan Bathara, 2014).

Data pada tabel 1 adalah hasil produksi pengolahan ikan pada tahun 2011 sd. 2013 untuk komoditas unggulan Kabupaten Kampar.

Tabel 1. Perkembangan Produksi Pengolahan Perikanan Desa Koto Mesjid

\begin{tabular}{|c|c|c|c|c|}
\hline \multirow{2}{*}{ No } & \multirow{2}{*}{ Komoditas } & \multicolumn{3}{|c|}{ Hasil Pengolahan Ikan $(\mathrm{kg})$} \\
\cline { 3 - 5 } & & 2011 & 2012 & 2013 \\
\hline 1 & Patin & 48.530 & 140.770 & 238.820 \\
\hline 2 & Mas & 8.671 & 15.972 & 18.380 \\
\hline 3 & Nila & 7.922 & 25.854 & 36.700 \\
\hline
\end{tabular}

Sumber: Kampung Patin, Kampar, Riau, 2015

Sentra pengolahan ikan Kampung Patin, Kampar, Riau terdiri dari Kelompok Pengolah dan Pemasar (Poklahsar) yang menaungi kelompok-kelompok usaha pengolahan ikan yang berada di Kampung Patin. Berikut adalah kelompok unit usaha yang dinaungi oleh Sentra Pengolahan Ikan Kampung Patin:

Tabel 2. Kelompok Unit Usaha Pada Sentra Penglolahan Ikan Kampung Patin

\begin{tabular}{|c|l|l|l|l|}
\hline No & $\begin{array}{l}\text { Nama } \\
\text { Kelompok }\end{array}$ & $\begin{array}{l}\text { Tahun } \\
\text { Berdiri }\end{array}$ & $\begin{array}{l}\text { Ketua } \\
\text { Kelompok }\end{array}$ & $\begin{array}{l}\text { Produk } \\
\text { Olahan }\end{array}$ \\
\hline 1 & Kim Salai & $\begin{array}{l}14 \text { Mei } \\
2012\end{array}$ & $\begin{array}{l}\text { Mustakim, } \\
\text { S.Pd }\end{array}$ & $\begin{array}{l}\text { Salai } \\
\text { Patin }\end{array}$ \\
\hline 2 & $\begin{array}{l}\text { Salai Patin } \\
\text { Zhidane }\end{array}$ & $\begin{array}{l}14 \mathrm{Mei} \\
2012\end{array}$ & Jabarullah & $\begin{array}{l}\text { Salai } \\
\text { Patin }\end{array}$ \\
\hline
\end{tabular}

\begin{tabular}{|c|l|l|l|l|}
\hline 3 & $\begin{array}{l}\text { Mitra } \\
\text { Salai }\end{array}$ & $\begin{array}{l}10 \\
\text { Maret } \\
2012\end{array}$ & Yendri & $\begin{array}{l}\text { Salai } \\
\text { Patin }\end{array}$ \\
\hline 4 & $\begin{array}{l}\text { Salai Dua } \\
\text { Putri }\end{array}$ & $\begin{array}{l}14 \text { Juni } \\
2012\end{array}$ & $\begin{array}{l}\text { Februs } \\
\text { Aperi }\end{array}$ & $\begin{array}{l}\text { Salai } \\
\text { Patin }\end{array}$ \\
\hline 5 & $\begin{array}{l}\text { Usaha } \\
\text { Mandiri }\end{array}$ & $\begin{array}{l}10 \\
\text { Agust } \\
2012\end{array}$ & $\begin{array}{l}\text { Yul } \\
\text { Khaidir }\end{array}$ & $\begin{array}{l}\text { Salai } \\
\text { Patin }\end{array}$ \\
\hline 6 & $\begin{array}{l}\text { Nugget } \\
\text { Sukaku }\end{array}$ & $\begin{array}{l}\text { Maret } \\
2013\end{array}$ & Murniati & $\begin{array}{l}\text { Nugget } \\
\text { Patin }\end{array}$ \\
\hline 7 & $\begin{array}{l}\text { Citra Rasa } \\
\text { Abon }\end{array}$ & $\begin{array}{l}\text { Maret } \\
2013\end{array}$ & Rosmaniar & $\begin{array}{l}\text { Abon } \\
\text { Patin }\end{array}$ \\
\hline 8 & $\begin{array}{l}\text { Bakso } \\
\text { Patin } \\
\text { Mandiri }\end{array}$ & $\begin{array}{l}\text { Maret } \\
2013\end{array}$ & Darmita & $\begin{array}{l}\text { Bakso } \\
\text { Abon }\end{array}$ \\
\hline 9 & $\begin{array}{l}\text { Pudung } \\
\text { Anugrah }\end{array}$ & $\begin{array}{l}\text { Maret } \\
2013\end{array}$ & Megawati & $\begin{array}{l}\text { Pudung } \\
\text { Patin }\end{array}$ \\
\hline
\end{tabular}

Sumber: Dinas Perikanan Kabupaten Kampar, Propinsi Riau, 2015

Tantangan UMKM saat ini adalah menghadapi perdagangan internasional dimana era ini telah meningkatkan persaingan bagi UMKM tidak hanya domestik melainkan internasional. Perdagangan internasional ini memberi dampak buruk terhadap UMKM yang tidak efisien atau yang berdaya saing rendah. Namun, akan menguntungkan UMKM yang efisien dan berdaya saing tinggi. Sentra pengolahan ikan Kampung Patin, Kampar, Riau sebagai salah satu UMKM yang tengah menghadapi era perdagangan internasional secara giat sedang mengembangkan usahanya yang pada akhirnya akan meningkatkan keefisienan dan daya saing mereka. Dengan latar belakang yang diuraikan sebelumnya, berdasarkan analisis dari berbagai referensi yang relevan mengenai tantangan perdagangan internasional terhadap sentra pengolahan ikan Kampung Patin, Kampar, Riau, maka penulis tertarik untuk melakukan penelitian dengan judul "analisis strategi pengembangan usaha pengolahan ikan pada kampung patin, kampar, riau".

Untuk memudahkan pembahasan masalah dan pemahamannya, maka penulis merumuskan permasalahan adalah "bagaimanakah strategi pengembangan usaha pengolahan ikan pada Kampung Patin, Kampar, Riau?"

Tujuan penelitian ini adalah untuk menganalisis strategi pengembangan usaha pengolahan ikan pada Kampung Patin, Kampar, Riau. Adapun manfaat penelitian ini diantaranya: 
a. Dapat memberikan pemahaman mengenai strategi pengembangan usaha, sehingga dapat menambah khasanah ilmu dalam suatu kerangka yang saling bersinergi. Juga dapat digunakan sebagai referensi studi atau penelitian selanjutnya dengan ruang lingkup yang berbeda.

b. Informasi ini digunakan sebagai referensi mengenai strategi pengembangan usaha pengolahan ikan dan menambah informasi dalam pertimbangan pembuatan keputusan, pengembangan dan koordinasi bagi UMKM/ bisnis yang terkait.

\section{KAJIAN TEORI}

Seperti halnya ikan lele, ikan patin tidak bersisik dan memiliki duri yang tajam di bagian siripnya, sehingga keduanya sama-sama digolongkan ke dalam jenis catfish. Namun demikian, rasa daging ikan patin lebih enak dan gurih dibandingkan dengan ikan lele. Ditambah lagi, produk ikan patin Indonesia terkenal bersih dan tidak mengeluarkan bau. Di beberapa daerah, ikan patin memiliki nama lain, seperti ikan Juara, Lancang dan Sodarin (djpen.kemendag.go.id, 2013).

Wilayah di Indonesia yang memiliki potensi untuk pengembangan industri ikan patin adalah Sumatera, Kalimantan dan Jawa. Dalam realisasinya, daerah yang terpilih untuk dijadikan sentra pengembangan industri ikan patin adalah Jambi, Riau dan Kalimantan Selatan. Jenis patin yang dikembangkan adalah Patin Jambal (Pangasius Djambal), Patin Siam (Pangasius Hypothalamus), dan Patin Pasupati (Pangasius SP) yang merupakan hasil persilangan antara pejantan Patin Jambal dan betina Patin Siam. Tujuan awal persilangan kedua jenis ikan patin tersebut adalah untuk memenuhi permintaan pasar ekspor yang menginginkan daging ikan patin berwarna putih. Selain warna dagingnya yang putih, ikan Patin Pasupati memiliki keunggulan dalam hal daya tahan yang lebih lama terhadap kondisi lingkungan perairan, dan mampu menghasilkan bibit yang lebih banyak (djpen.kemendag.go.id, 2013).

Ikan salai yang berasal dari ikan patin itu diolah atau dibakar tidak menggunakan penyedap rasa atau aroma serta juga tidak pakai formalin sebagai bahan pengawet ikan.Ikan salai Patin (ikan asap Patin) merupakan olahan ikan segar yang diawet dengan mengunakan asap dan api yang dikerjakan secara tradisional.

Pengembangan usaha dapat dilakukan dengan berbagai strategi diantaranya adalah (swa.co.id, 2013):

a. Strategi penetrasi pasar dilakukan dengan menambah penjualan di pasar yang saat ini dilayani dengan produk yang ada,

b. Strategi pengembangan produk dilakukan dengan menambah produk baru di pasar,

c. Strategi pengembangan pasar dilakukan dengan memperluas wilayah pemasaran, atau

d. Strategi memperluas segmen pasar dengan menggunakan produk yang sudah ada (existing products).

Banyak perusahaan mengembangkan usaha secara disiplin yakni memulai dengan memanfaatkan keunggulan produk, modal, jejaring, reputasi, dan kompetensi untuk melayani wilayah atau segmen pasar yang baru dengan membuka cabang atau mengembangkan sistem waralaba.Pola pengembangan usaha yang seperti ini akan memperkecil risiko sekaligus memperbesar peluang keberhasilan.Pola pengembangan usaha secara disiplin tersebut telah berhasil dilakukan oleh Olam, sebuah perusahaan multinasional dari Nigeria (swa.co.id, 2013).

Penelitian ini menggunakan alat analisis SWOT yang dilakukan dalam beberapa tahapan. Langkah pertama yang dilakukan yaitu mengidentifikasi masing masing faktor internal (kekuatan dan kelemahan) dan faktorfaktor eksternal (peluang dan hambatan) pada usaha pengolahan ikan di Kampung Patin. Setelah proses identikasi, tahap selanjutnya yaitu merumuskan faktor-faktor tersebut ke dalam matrik SWOT yang kemudian dianalisis berdasarkan ketentuannya untuk memperoleh strategi alternatif yang berdaya saing dalam pemasaran ikan hasil olahan tersebut. Matrik SWOT dapat dilihat pada Tabel 3.

Berdasarkan pertimbangan kombinasi empat faktor strategi (kekuatan, kelemahan, peluang, dan hambatan), sehingga menghasilkan empat kelompok faktor strategi sebagai berikut:

a. Strategi SO yaitu strategi yang dibuat dengan memanfaatkan seluruh kekuatan 
untuk merebut dan memanfaatkan peluang sebesar-besarnya;

b. Strategi ST yaitu strategi untuk menggunakan kekuatan yang dimiliki oleh usaha dengan cara menghindarai hambatan; c. Strategi WO yaitu strategi yang diterapkan berdasarkan pemanfaatan peluang yang ada dengan cara mengatasi kelemahan-kelemahan yang dimiliki;

d. Strategi WT yaitu strategi yang didasarkan pada kegiatan yang ditujukan untuk meminimalkan kelemahan yang ada serta menghindari hambatan.

Tabel 3. Analisis SWOT

\begin{tabular}{|c|c|c|}
\hline $\mathrm{P}_{\text {Eksternal }}^{\text {Internal }}$ & $\begin{array}{l}\text { Strengths }(\mathrm{S}) \\
\text { Tentukan kekuatan faktor- } \\
\text { faktor internal }\end{array}$ & $\begin{array}{l}\text { Weaknesses }(\mathrm{W}) \\
\text { Tentukan faktor-faktor kelemahan } \\
\text { internal }\end{array}$ \\
\hline $\begin{array}{l}\text { Oppurtunities }(\mathrm{O}) \\
\text { Tentukan faktor-faktor } \\
\text { peluang internal }\end{array}$ & $\begin{array}{l}\text { Strategi S-O } \\
\text { Ciptakan strategi yang } \\
\text { menggunakan kekuatan } \\
\text { untuk memanfaatkan } \\
\text { peluang }\end{array}$ & $\begin{array}{l}\text { Strategi W-O } \\
\text { Ciptakan strategi yang } \\
\text { meminimalkan kelemahan untuk } \\
\text { memanfaatkan pe- } \\
\text { Luang }\end{array}$ \\
\hline $\begin{array}{l}\text { Threats } \\
\text { Tentukan faktor ham- } \\
\text { batan internal (T) }\end{array}$ & $\begin{array}{l}\text { Srategi S-T } \\
\text { Ciptakan strategi yang } \\
\text { menggunakan kekuatan } \\
\text { untuk mengatasi hambatan }\end{array}$ & $\begin{array}{l}\text { Strategi W-T } \\
\text { Ciptakan strategi yang } \\
\text { meminimalkan kelemahan dan } \\
\text { menghindari hambatan }\end{array}$ \\
\hline
\end{tabular}

Sumber: Rangkuti (2006)

Terdapat penelitian yang dilakukan sebelumnya yang terkait dengan penelitian ini, seperti pada tabel 4 berikut.

Tabel 4. Daftar Penelitian Terdahulu yang Terkait

\begin{tabular}{|c|l|l|}
\hline No & Peneliti (Tahun) & \multicolumn{1}{|c|}{ Judul Penelitian } \\
\hline 1. & $\begin{array}{l}\text { Sesni Hasnibar, } \\
\text { Hamdi Hamid } \\
\text { dan and Lamun } \\
\text { Bathara (2014) }\end{array}$ & $\begin{array}{l}\text { Strategi Pemasaran } \\
\text { Produk Olahan Ikan } \\
\text { Patin (Pangasius } \\
\text { Sutchi) Di Desa Koto } \\
\text { Mesjid Kecamatan } \\
\text { XIII Koto Kampar } \\
\text { Kabupaten Kampar } \\
\text { Provinsi Riau }\end{array}$ \\
\hline 2. & $\begin{array}{l}\text { Wahyuniarso, } \\
\text { Tri DS. (2013) }\end{array}$ & $\begin{array}{l}\text { Strategi } \\
\text { Pengembangan } \\
\text { Industri Kecil } \\
\text { Keripik di Dusun } \\
\text { Karangbolo Desa } \\
\text { Lerep Kabupaten } \\
\text { Semarang. Semarang }\end{array}$ \\
\hline
\end{tabular}

Sumber: Hasnibar, Hamid dan Bathara (2014); Wahyuniarso (2013)

\section{METODE}

Penelitian ini mengambil lokasi di Sentra Pengolahan Ikan, Kampung Patin, Desa Koto Mesjid, Kecamatan XIII Koto Kampar, Kabupaten Kampar, Riau. Alasan peneliti adalah karena UMKM ini merupakan UMKM yang telah didaulat sebagai salah satu sentra pengolahan ikan di Indonesia dan kawasan minapolitan yang memiliki tantangan untuk menghadapi perdagangan internasional dimana era ini telah meningkatkan persaingan bagi UMKM tidak hanya domestik melainkan internasional.

Analisis data yang digunakan pada penelitian ini adalah analisis deskriptif dan kualitatif. Analisis ini dilakukan untuk mendapatkan gambaran deskriptif mengenai variabel penelitian yang digunakan.

\section{HASIL DAN PEMBAHASAN}

\section{Deskripsi Proses Pengolahan Ikan di Sentra Pengolahan Ikan Kampung Patin}

Produk unggulan sentra pengolahan ikan Kampung Patin adalah ikan salai patin. Dalam seminggu produksi ikan salai patin ini menggunakan bahan baku dan bahan penunjang dalam proses produksinya. Bahan 
baku yang digunakan pengolah untuk memproduksi ikan salai patin adalah ikan patin segar, kayu bakar, dan minyak tanah. Kayu bakar yang digunakan pengolah di Desa Koto Mesjid adalah kayu rambutan. Alasan pengolah menggunakan kayu rambutan adalah karena kayu rambutan keras, apinya kuat dan asap yang ditimbulkan sedikit (Siagian; Ramli dan Nugroho, 2014).

Secara sistematis, langkah-langkah dalam pengolahan ikan patin hingga menjadi ikan salai dideskripsikan sebagai berikut. Pengolahan ikan salai berasal dari ikan patin segar yang dipanen berumur empat bulan.Sedangkan proses pembuatan ikan salai adalah dimulai dari pemanenan ikan patin langsung dari kolam kemudian dibersihkan insangnya. Selanjutnya, ikan patin dibelah menjadidua pada bagian tengah tanpa terputus, lalu dimasukkan kedalam air yang berada dalam bak pertama. Ikan patin yang sudah dipotong yang berada dalam rendaman bak pertama dipindahkan lagi ke bak kedua direndam kembali dan juga ditunggu beberapa menit untuk menghilangkan kandungan darah ikan patin yang dibelah tersebut, sebelum akhirnya dibakar pada pembakaran yang sudah disediakan hingga matang.Selanjutnya ikan tersebut diangkat dan didinginkan untuk segera siap dikemas (Siagian; Ramli dan Nugroho, 2014 serta djpen.kemendag.go.id, 2013).

\section{Analisis Strategi Pengembangan Usaha Pengolahan Ikan di Kampung Patin \\ a. Fakor Lingkungan Internal \\ 1). Kekuatan (Strengths) \\ a). Ketersediaan Sumber Daya Manusia (SDM) sesuai dengan kebutuhan.}

Sentra Pengolahan Ikan Kampung Patin memiliki SDM yang cukup dengan pembekalan pendidikan dan pelatihan yang didapat, baik dari Universitas maupun penyediaan pelatihan oleh bisnis maupun pemerintah kabupaten hingga nasional. Adanya Pusat Pelatihan Mandiri Kelautan dan Perikanan (P2MKP) sebagai fasilitas peningkatan SDM petani tentang teknis budidaya, pembuatan pakan dan pengolahan ikan, mencari upaya pengadaan modal dengan pihak perbankan dan lembaga lain, mengadakan pelatihan bekerjasama dengan pihak sponsor dan Balai Pelatihan maupun Universitas. b). Produk olahan ikan yang sesuai dengan kebutuhan dan pola konsumsi konsumen domestik dan internasional.

Ikan salai yang berasal dari ikan patin diolah atau dibakar tidak menggunakan penyedap rasa atau aroma serta juga tidak pakai formalin sebagai bahan pengawet ikan. Salai ikan patin menjadi sangat digemari konsumen di pasar Singapura dan Malaysia tersebut karena rasanya yang gurih dan tidak mengandung pengawet atau pun penyedap rasa. Sebelum ikan salai patin, telah dikenal dipasaran terlebih dahulu ikan salai selais dan baung yang harganya jauh lebih mahal dari salai patin (djpen.kemendag.go.id, 2013).

c). Diversifikasi produk olahan ikan yang variatif

Dalam rangka menampung ikan sebagai hasil budidaya yang melimpah di Kampung Patin, maka dilakukan usaha pengolahan ikan yang terdiri atas ikan salai, abon ikan, nugget ikan, pudung dan bakso ikan. Meskipun jumlah pengolahan tersebut tidak sebanyak pengolahan ikan salai, namun hasil olahan ikan patin menjadi produk banyak digemari oleh konsumen propinsi Riau terutama nugget dan bakso ikan patin. Upaya pengolahan ikan patin menjadi beberapa produk diversifikasi olahan tersebut akan membuat produk olahan bertahan \pm 3-4 bulan disimpan dalam wadah penyimpanan dan kemasan yang digunakan Hasnibar, Hamid, dan Bathara (2014). Diversifikasi produk olahan hasil perikanan bertujuan untuk memberikan nilai tambah yang lebih tinggi jika dibandingkan dengan penjualan hasil perikanan dalam bentuk ikan mentah/ ikan segar.

d). Harga produk olahan ikan dari Kampung Patin yang terjangkau dan bersaing

Sebelum ikan salai patin, telah dikenal dipasaran terlebih dahulu ikan salai selais dan baung yang harganya jauh lebih mahal dari salai patin (djpen.kemendag.go.id, 2013). Sedangkan jika dibandingkan kualitas ikan salai patin dari Kampung Patin dengan produksi usaha di Jakarta dan Bandung, dinilai konsumen rasanya lebih gurih dan enak.

2). Kelemahan (Weaknesses)

a). Jangkauan pemasaran yang terbatas

Dalam hal pemasaran, sentra pengolahan ikan Kampung Patin tidak mempunyai sumber-sumber daya untuk mencari, mengembangkan atau memperluas 
pasar-pasar mereka sendiri. Sebaliknya, merekasangat tergantung pada mitra dagang mereka (pengumpul) untuk memasarkan produk-produk mereka, dan juga bergantung pada konsumen yang datang. Ikan salai patin yang diproduksi dipasarkan ke Pasar Bangkinang, Air Tiris, dan Kuok. Dari agen/ pengumpul kemudian ikan patin menyebar ke Pekanbaru, Siak, Batam, Jambi, Jakarta, Aceh hingga ke negeri tetangga Malaysia dan Singapur. Untuk pasokan ikan salai pengolah langsung memasarkan dari sentra UPTD dan diantar ketiga tempat tadi. Setelah itu baru dipasarkan lagi kedaerah lain hingga ke luar negeri.

Pada proses pendistribusian ini, memperlihatkan bahwa kegiatan ekspor salaiikan patin dari Kampung Patin belum dilakukan berdasarkan prosedur ekspor yang berlaku dalam peraturan perdagangan internasional di Indonesia (djpen.kemendag.go.id, 2013).

b). Teknik pengemasan yang kurang baik dan menarik

Teknik pengemasan merupakan kelemahan dari UMKM di Indonesia pada umumnya. khususnya teknik pengemasan yang selain berfungsi untuk pengaman produk, juga perlu memperhatikan estetika agar tampil lebih menarik. Dengan pengemasan yang baik, menarik dan inovatif, maka konsumen baik domestik maupun pasar tujuan ekspor untuk komoditas salai ikan patin dan olahan patin lainnya dapat diperluas hingga ke pasar di kawasan lainnya, yang juga memiliki permintaan tinggi terhadap ikan patin seperti AS, Eropa dan Timur Tengah (djpen.kemendag.go.id, 2013).

c). Kurangnya kepekaan pengusaha terhadap perubahan selera konsumen yang dipengaruhi oleh gaya hidup, ekonomi, sosial dan budaya.

Dalam mengembangkan usahanya sentra pengolahan ikan Kampung Patin dinilai masih kurangnya kepekaan terhadap selera pasar yang sangat dipengaruhi oleh gaya hidup, ekonomi, sosial, dan budaya. Penguasaan dan pemanfaatan teknologi untuk menghasilkan produk yang berkualitas juga sangat diperlukan untuk memperbesar kemungkinan produk tersebut diterima oleh konsumen secara luas (djpen.kemendag.go.id, 2013). Mengingat persaingan bisnis saat ini menjadi semakin luas dengan memasuki era perdagangan internasional.

\section{b. $\quad$ Fakor Lingkungan Eksternal \\ 1). Peluang (Opportunities) \\ a). Pasar Potensial Dalam dan Luar Negeri}

Pasar potensial produk olahan ikan dari Kampung Patin tidak hanya pasar domestik, namun pasar internasional (negara ASEAN maupun AS, Eropa dan Timur Tengah). Salah satu pasar internasional yang menyediakan peluang ekspor untuk produk makanan olahan adalah Korea. Total nilai produk makanan olahan yang diimpor Korea dari seluruh dunia adalah USD 7,13 miliar di tahun 2008, dan meningkat menjadi USD 8,43 miliar di tahun 2012. Dengan menganalisis data tersebut, dapat disimpulkan bahwa Kampung Patin sebagai salah satu UMKM andalan di Indonesia baru memanfaatkan sebagian kecil peluang pasar yang tersedia di Korea, untuk komoditas olahan ikan (djpen.kemendag.go.id, 2013).

b). Proyeksi Kebutuhan Konsumsi Ikan Masyarakat Kab. Kampar Meningkat Signifikan.

Berdasarkan data dari Dinas Perikanan Kab. Kampar, bahwa proyeksi kebutuhan produk olahan ikan guna memenuhi kebutuhan untuk konsumsi masyarakat umum khususnya di Kabupaten Kampar pada tahun 2010-2014 diperkirakan terus mengalami peningkatan. Tahun 2010, kebutuhan masyarakat Kabupaten Kampar 21.784, terus meningkat hingga tahun 2011 menjadi 23.824, tahun 2012 menjadi 25.970, tahun 2013 menjadi 28.220 dan tahun 2014 terus meningkat signifikan menjadi 30.564.

c). Kampung Patin dikenal di Indonesia dan internasional sebagai sentra pengolahan ikan dan kawasan minopolitan.

Kampung Patin telah mendunia. Melalui

Surat Keputusan Direktorat Jendral Pengolahan dan Pemasaran Hasil Perikanan (P2HP) No. Kep.69/DJ-P2HP/2007 tanggal 5 Juni 2007 yang menyatakan bahwa Kabupaten Kampar merupakan "Lokasi Pengembangan Sentra Pengolahan Hasil Perikanan". Selain itu, penetapan Kabupaten Kampar sebagai kawasan sentra produksi perikanan air tawar di Prov. Riau melalui Surat Kep. Gubernur Riau No. KPTS/99/II/2000 tanggal 28 Februari 2000, dan baru pada tahun 2010 ditetapkan sebagai kawasan Minapolitan. Melalui 
Keputusan Menteri Kelautan dan Perikanan RI No. Kep.32/Men/2010 tentang Penetapan Kawasan Minapolitan, ditetapkan bahwa kawasan Minapolitan di Provinsi Riau berada di Kab. Kampar, yang dipusatkan pada wilayah Kecamatan XIII Koto Kampar dengan minapolis berada di Desa Koto Mesjid.

2). Ancaman (Threats)

a). Biaya Produksi yang Semakin Tinggi Akibat Pakan Ikan Tergantung pada Impor

Tantangan yang krusial yang masih dihadapi oleh sentra pengolahan ikan Kampung Patin adalah yaitu ongkos produksinya yang makin lama semakin meningkat, yakni sebesar Rp $8.000-\mathrm{Rp}$ 11.000 per $\mathrm{kg}$. Biaya ini lebih mahal bila dibandingkan dengan di Vietnam yang hanya Rp 6.000 per kg. Akibatnya, harga jual ikan patin dari Vietnam pun menjadi lebih murah, yaitu $\mathrm{Rp} 12.000$ per $\mathrm{kg}$, di pasar internasional. Hal tersebut terjadi karena pakannya masih tergantung pada impor. Ini berbeda dengan Vietnam yang sudah mampu memproduksi sendiri.

(djpen.kemendag.go.id, 2013).

b). Belum optimalnya pemanfaatan potensi lahan dan usaha pengolahan yang ada untuk mengoptimasi hasil produksi olahan ikan.

Sentra pengolahan ikan Kampung Patin masih belum mengoptimalkan potensi lahan dan usaha pengolahan yang ada untuk mengoptimasi hasil produksi olahan ikan. Ketidakefisienan tersebut menjadi tantangan bagi sentra pengolahan ikan Kampung Patin untuk tetap dapat bertahan dalam persaingan.

c). Persaingan bisnis yang tidak terbatas di era perdagangan internasional.

Tantangan UMKM saat ini pada umumnya adalah menghadapi perdagangan internasional, seperti Masyarakat Ekonomi ASEAN (MEA) 2015, dimana era ini telah meningkatkan persaingan bagi UMKM tidak hanya domestik melainkan internasional. Perdagangan internasional ini akan memberi dampak buruk bagi UMKM yang berdaya saing rendah. Namun, akan menguntungkan UMKM yang berdaya saing tinggi.

\section{Analisis Matriks SWOT}

Berdasarkan identifikasi faktor lingkungan internal dan eksternal yang telah dibahas sebelumnya, tabel 5 berikut merumuskan matriks SWOT.

Tabel 5. Matriks SWOT pada Sentra Pengolahan Ikan Kampung Patin

\begin{tabular}{|c|c|c|}
\hline$\overbrace{\text { EFAS }}^{I F A S}$ & Strengths & Weaknesses \\
\hline & $\begin{array}{l}\text { a). Ketersediaan } \\
\text { Sumber } \\
\text { Daya } \\
\text { Manusia } \\
\text { (SDM) } \\
\text { sesuai } \\
\text { dengan } \\
\text { kebutuhan } \\
\text { · } \\
\text { b). Produk } \\
\text { olahan } \\
\text { ikan yang } \\
\text { sesuai } \\
\text { dengan } \\
\text { kebutuhan } \\
\text { dan pola } \\
\text { konsumsi } \\
\text { konsumen } \\
\text { domestik } \\
\text { dan } \\
\text { internasio } \\
\text { nal. } \\
\text { c).Diversifikasi } \\
\text { produk } \\
\text { olahan } \\
\text { ikan yang } \\
\text { variatif } \\
\text { Harga } \\
\text { produk } \\
\text { olahan } \\
\text { ikan dari } \\
\text { Kampung } \\
\text { Patin } \\
\text { yang } \\
\text { terjangkau } \\
\text { dan } \\
\text { bersaing }\end{array}$ & 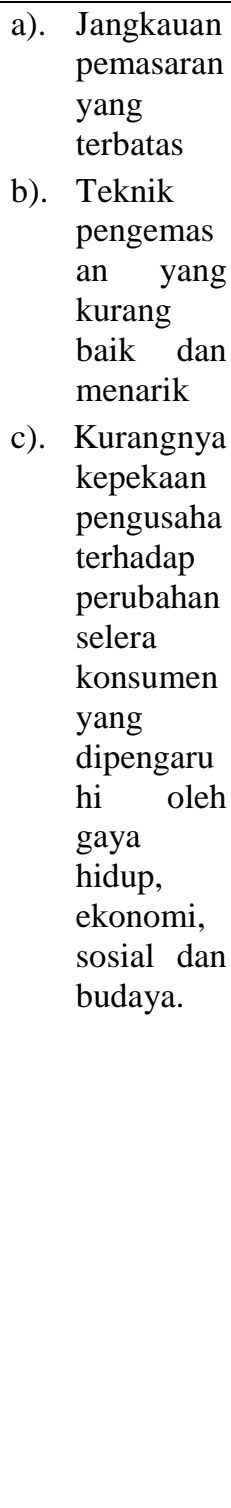 \\
\hline Opportunities & Strategi SO & Strategi WO \\
\hline $\begin{array}{l}\text { a. Pasar } \\
\text { potensial } \\
\text { dalam dan luar } \\
\text { negeri } \\
\text { b. Proyeksi } \\
\text { kebutuhan } \\
\text { konsumsi ikan } \\
\text { masyarakat } \\
\text { Kab. Kampar } \\
\text { meningkat } \\
\text { signifikan. }\end{array}$ & $\begin{array}{l}\text { a.Pemberdayaan } \\
\text { SDM setempat } \\
\text { untuk } \\
\text { meningkatkan } \\
\text { volume } \\
\text { produksi guna } \\
\text { meningkatkan } \\
\text { pemenuhan } \\
\text { kebutuhan } \\
\text { pasar dalam } \\
\text { dan luar negeri }\end{array}$ & $\begin{array}{l}\text { a. Perluasan } \\
\text { jangkauan } \\
\text { pemasaran } \\
\text { hingga ke luar } \\
\text { negeri dengan } \\
\text { mengikuti } \\
\text { pelatihan } \\
\text { prosedur } \\
\text { ekspor dari } \\
\text { pemerintah c.q. } \\
\text { DJPEN, } \\
\text { Kementerian }\end{array}$ \\
\hline
\end{tabular}




\begin{tabular}{|c|c|c|}
\hline $\begin{array}{l}\text { c. Kampung } \\
\text { Patin dikenal } \\
\text { di Indonesia } \\
\text { dan } \\
\text { internasional } \\
\text { sebagai sentra } \\
\text { pengolahan } \\
\text { ikan dan } \\
\text { kawasan } \\
\text { minopolitan. }\end{array}$ & $\begin{array}{l}\text { b. Semakin } \\
\text { meningkat-kan } \\
\text { kualitas produk } \\
\text { olahan ikan } \\
\text { melalui } \\
\text { higienitas } \\
\text { produk dan } \\
\text { sanitasi lokasi } \\
\text { produksi guna } \\
\text { mendapatkan } \\
\text { SNI. Kedua hal } \\
\text { ini sangat } \\
\text { terkaitan } \\
\text { dengan standar } \\
\text { kesehatan di } \\
\text { sejumlah } \\
\text { negara agar } \\
\text { berhasil } \\
\text { melakukan } \\
\text { penetrasi ke } \\
\text { pasar dunia. }\end{array}$ & $\begin{array}{l}\text { Perdagangan } \\
\text { sehingga } \\
\text { aktivitas } \\
\text { perdagangan } \\
\text { internasional } \\
\text { membaik. } \\
\text { b. Peningkatan } \\
\text { keter-kaitan } \\
\text { produksi } \\
\text { melalui } \\
\text { misalnya } \\
\text { subcontracting } \\
\text { antara UMKM } \\
\text { dan Usaha } \\
\text { Besar (UB) } \\
\text { dengan } \\
\text { meningkatkan } \\
\text { kemampuan } \\
\text { mereka sebagai } \\
\text { pemasok yang } \\
\text { kompetitif dan } \\
\text { efisien bagi } \\
\text { UB } \\
\text { pemerintah dari } \\
\text { bersama-sama } \\
\text { dengan pihak } \\
\text { swasta seperti } \\
\text { Kadin, asosiasi } \\
\text { bisnis, } \\
\text { himpunan } \\
\text { pengusaha, dan } \\
\text { universitas. }\end{array}$ \\
\hline Threats & Strategi TS & Strategi TW \\
\hline $\begin{array}{l}\text { a. } \\
\text { Produksi yang } \\
\text { Semakin } \\
\text { Tinggi Akibat } \\
\text { Pakan Ikan } \\
\text { Tergantung } \\
\text { pada Impor } \\
\text { b. Belum } \\
\text { optimalnya } \\
\text { pemanfaatan } \\
\text { potensi lahan } \\
\text { dan usaha } \\
\text { pengolahan } \\
\text { yang ada untuk } \\
\text { mengoptimasi } \\
\text { hasil produksi } \\
\text { olahan ikan. } \\
\text { c. Persaingan } \\
\text { bisnis yang } \\
\text { tidak terbatas } \\
\text { di pana } \\
\text { perdagangan } \\
\text { internasional. }\end{array}$ & $\begin{array}{l}\text { a.Meningkatkan } \\
\text { kompetensi } \\
\text { SDM yang } \\
\text { dimiliki } \\
\text { sehingga siap } \\
\text { membangun } \\
\text { klaster } \\
\text { budidaya ikan } \\
\text { patin yang } \\
\text { tersentralisasi } \\
\text { agar biaya } \\
\text { produksi bisa } \\
\text { ditekan dan } \\
\text { volume } \\
\text { produksi } \\
\text { olahan ikan } \\
\text { bisa } \\
\text { ditingkatkan. } \\
\text { b. Semakin } \\
\text { meningkat-kan } \\
\text { kreatifitas dan } \\
\text { keinovatifan } \\
\text { pengusaha } \\
\text { guna } \\
\text { menambah } \\
\text { diversifikasi } \\
\text { produk olahan }\end{array}$ & $\begin{array}{l}\text { a.Mengupayak } \\
\text { an pe- } \\
\text { ngemasan yang } \\
\text { baik, menarik } \\
\text { dan inovatif, } \\
\text { maka pasar } \\
\text { dapat diperluas } \\
\text { hingga ke } \\
\text { pasar di } \\
\text { kawasan } \\
\text { lainnya, yang } \\
\text { juga memiliki } \\
\text { permintaan } \\
\text { tinggi. } \\
\text { b.Meningkatkan } \\
\text { jalinan } \\
\text { kerjasama } \\
\text { antara } \\
\text { Kampung } \\
\text { Patin dengan } \\
\text { Triple Helix } \\
\text { sehingga } \\
\text { terjadi } \\
\text { modernisasi } \\
\text { sarana dan } \\
\text { teknologi }\end{array}$ \\
\hline
\end{tabular}

\begin{tabular}{|l|l|l|}
\hline & ikan untuk & pendukung ke \\
memenuhi & UMKM untuk \\
berbagai pola & meningkatkan \\
konsumsi dari & efisiensi dan \\
pasar domestik & daya saing. \\
dan & \\
internasional. & \\
\hline
\end{tabular}

Sumber: Data Olahan, 2015

\section{SIMPULAN DAN SARAN}

\section{Simpulan}

Berdasarkan sejumlah faktor lingkungan internal dan faktor lingkungan internal dan eksternal, maka strategi pengembangan usaha pengolahan ikan Kampung Patin yang penting untuk diimplementasikan adalah:
a. Pemberdayaan SDM setempat untuk meningkatkan volume produksi guna meningkatkan pemenuhan kebutuhan pasar dalam dan luar negeri.

b. Semakin meningkatkan kualitas produk olahan ikan melalui higienitas produk dan sanitasi lokasi produksi guna mendapatkan SNI. Kedua hal ini sangat terkaitan dengan standar kesehatan di sejumlah negara agar berhasil melakukan penetrasi ke pasar dunia.

c. Perluasan jangkauan pemasaran hingga ke luar negeri dengan mengikuti pelatihan prosedur ekspor dari pemerintah c.q. DJPEN, Kementerian Perdagangan sehingga aktivitas perdagangan internasional membaik.

d. Peningkatan keterkaitan produksi melalui misalnya subcontracting antara UMKM dan Usaha Besar (UB) dengan meningkatkan kemampuan mereka sebagai pemasok yang kompetitif dan efisien bagi UB dari pemerintah bersama-sama dengan pihak swasta seperti Kadin, asosiasi bisnis, himpunan pengusaha, dan universitas.

e. Meningkatkan kompetensi SDM yang dimiliki sehingga siap membangun klaster budidaya ikan patin yang tersentralisasi agar biaya produksi bisa ditekan dan volume produksi olahan ikan bisa ditingkatkan.

f. Semakin meningkatkan kreatifitas dan keinovatifan pengusaha guna menambah diversifikasi produk olahan ikan untuk memenuhi berbagai pola konsumsi dari pasar domestik dan internasional. 
g. Mengupayakan pengemasan yang baik, menarik dan inovatif, maka pasar dapat diperluas hingga ke pasar di kawasan lainnya, yang juga memiliki permintaan tinggi.

h. Meningkatkan jalinan kerjasama antara Kampung Patin dengan Triple Helix sehingga terjadi modernisasi sarana dan teknologi pendukung ke UMKM untuk meningkatkan efisiensi dan daya saing.

\section{Saran}

Walaupun pembahasan secara empirik strategi pengembangan usaha merupakan hal yang sudah umum dilakukan, namun hingga saat ini orientasi utama yang harus terus menjadi fokus utama setiap UMKM adalah strategi pengembangan usaha mengingat UMKM umumnya dan sentra pengolahan ikan Kampung Patin khususnya saat ini telah menghadapi era perdagangan internasional. Karena hal tersebut sekaligus meningkatkan tuntutan UMKM untuk meningkatkan keefisienan maupun daya saing nya.

Berdasarkan hasil penelitian, maka bagi setiap UMKM bahwa berbicara strategi pengembangan usaha, hal yang sangat vital adalah implementasi. Karena sebagian besar kegagalan dari strategi pengembangan usaha adalah formulasi strategi yang hanya tinggal diatas kertas.

Perlu ditekankan bahwa dalam pengembangan usaha kita tidak boleh hanya tergiur pada besarnya hasil yang dicapai, tapi juga harus dapat mengukur/ memperhitungkan sumberdaya yang dimiliki terhadap pengembangan usaha yang baru dan kemungkinan keberhasilannya. Karena mengembangkan usaha secara bertahap merupakan strategi penting, terutama bagi UMKM baru.

\section{DAFTAR PUSTAKA}

djpen.kemendag.go.id (20 Oktober 2013). Ikan Patin Hasil Alam Bernilai Ekonomi dan Berpotensi Ekspor Tinggi. Direktorat
Jenderal Pengembangan Ekspor Nasional (DJPEN). Diakses melalui http://djpen.kemendag.go.id/app_fronten d/admin/docs/publication/82413842335 98.pdf pada 15 Desember 2015

Hasnibar, Sesni; Hamid, Hamdi dan Bathara, Lamun (2014). Strategi Pemasaran Produk Olahan I Kan Patin (Pangasius Sutchi) Di Desa Koto Mesjid Kecamatan XIII Koto Kampar Kabupaten Kampar Provinsi Riau. Fakultas Perikanan dan Ilmu Kelautan, Universitas Riau.

Juliandi, Azuar; Irfan dan Manurung, Saprinal (2014). Metode Penelitian Bisnis: Konsep dan Aplikasi. Medan: UMSU Press.

Rangkuti, Freddy (2006). Analisis SWOT: Teknik Membedah Kasus Bisnis. Jakarta: PT. Gramedia Pustaka Utama.

Siagian, Mastaulina; Ramli, M dan Nugroho, Firman. (2014). Analisis Titik Impas (Break Even Point) Usaha Pengolahan Ikan Salai Patin Di Desa Koto Mesjid Kecamatan Xiii Koto Kampar Kabupaten Kampar Provinsi Riau. Jurnal Online Mahasiswa, Universitas Riau.

swa.co.id (25 April 2013). Mengembangkan Usaha Secara Disiplin. Majalah SWA no. 09 XXIX. Triono Saputro. Diakses pada 9 Nopember 2015.

telkom.co.id (19 Februari 2013). Koto Mesjid, Desa Binaan Telkom dan Pemerintah Kabupaten Kampar yang Sukses Menjadi "Kampung Patin". Diakses melalui http://www.telkom.co.id/kotomesjid-desa-binaan-telkom-danpemerintah-kabupaten-kampar-yangsukses-menjadi-kampung-patin.html pada 15 Desember 2015

Wahyuniarso, Tri DS. (2013). Strategi Pengembangan Industri Kecil Keripik di Dusun Karangbolo Desa Lerep KabupatenSemarang. Semarang: Skripsi S1 Universitas Negeri Semarang. 